\title{
ARTICLE \\ Identification of an Appropriate Formulation for Domestic Water Ce- ramic Filters from Soukamna Clay (Cameroon)
}

\author{
Ngiongboung Nguiamba ${ }^{*}$ Celestine Asobo Yanu Placide Désiré Belibi Belibi \\ Joseph Marie Sieliechi Martin Benoît Ngassoum \\ National School of Agro-Industrial Sciences, Department of Applied Chemistry, University of Ngaoundéré, \\ Ngaoundéré, Cameroon
}

\section{ARTICLE INFO}

Article history

Received: 13 July 2021

Accepted: 15 July 2021

Published Online: 20 July 2021

Keywords:

Ceramic filter

Porosity

Permeability

Iron leaching

Soukamna

\begin{abstract}
This paper deals with the formulation of ceramic filters having the porosity adapted to domestic potable water treatment. The filters were made from clays and rice husk obtained from the Far North region of Cameroon (Logone Valley). Nine formulations were investigated to choose those that might have the porosity standing between 35 and $50 \%$ (the ideal porosity adapted for water treatment). The nine formulations investigated were as follows: clay:rice husk mixture weight ratio $0.7: 0.3 ; 0.8: 0.2$ and 0.9:0.1 with the particle size of 100:100 microns. The sintering temperatures of 900 ${ }^{\circ} \mathrm{C}, 950{ }^{\circ} \mathrm{C}$ and $1000{ }^{\circ} \mathrm{C}$ were applied for each of the mixtures. The results showed that only filters with weight ratio $0.7: 0.3$ sintered at $900{ }^{\circ} \mathrm{C}, 950{ }^{\circ} \mathrm{C}$ and $1000{ }^{\circ} \mathrm{C}$ had porosity between 35 and $50 \%$ with values of $39.41 \pm 0.96$; $40.15 \pm 1.59 ; 40.14 \pm 1.31$ respectively. Mechanical strength, permeability and iron leaching behavior were investigated for these three formulations. The formulation 0.7:0.3 with sintering temperature of $1000{ }^{\circ} \mathrm{C}$ had the higher permeability and was the more stable for iron leaching so it is the more adapted for water treatment in terms of flow rate and iron leaching behavior, pore size distribution showed that these filters were macroporous and designed for microfiltration with average pore diameter of $0.46 \mu \mathrm{m}$.
\end{abstract}

ensure a high flow rate and an efficiency against microbial pollutant ${ }^{[3]}$. Previous works have shown that filters based on clays of the Far North region of Cameroon can leach iron on the filtrate. Many parameters could influence the porosity and the leaching behavior of a ceramic filter such as the sintering temperature and the percentage of porogen. Determine the best formulation that ensures the ideal porosity and the lower leaching behavior is therefore a crucial task for a clay-rice husk mixture.

In this research, ceramic filters based on materials from Far North region of Cameroon (clay and rice husk) were formulated. Study of the effect of weight ratio (clay and rice husks) and sintering temperature on porosity of the

*Corresponding Author:

Ngiongboung Nguiamba,

National School of Agro-Industrial Sciences, Department of Applied Chemistry, University of Ngaoundéré, Ngaoundéré, Cameroon Email: ronnynguiamba@gmail.com 
filters was done. This was done to choose the formulation (weight ratio and sintering temperature) that gives the porosity between 35 and $50 \%$. Then the study of the effect of temperature on mechanical strength, permeability and iron leaching behavior of the having porosity between 35 and $50 \%$ was done. Finally, pore size distribution was investigated on the formulation with the higher permeability and the lower iron leaching behavior.

\section{Experimental}

\subsection{Sampling of Raw Materials}

Clay material was collected at a mining site located at Soukamna (Far North region of Cameroon) altitude $321 \mathrm{~m}$, latitude $10.34716^{\circ} \mathrm{N}$ and longitude $15.26525^{\circ} \mathrm{E}$. Rice husks were collected at Yagoua (Far North region of Cameroon) market. After collected, the clay and rice husks were stored and dried at room temperature in the laboratory. The clay was grind using an artisanal (made of wood) mortar while the rice husk was grind using a grinding mill (farmer mill used to grind corn). The clay and rice husk were sieved through a $100 \mu \mathrm{m}$ sieve.

\subsection{Ceramic Body Preparation}

Sieved clay and rice husk were then mixed at different ratios 0.7:0.3, 0.8:0.2 and 0.9:0.1 (by weight) followed by making dough by adding water. This leads to what is called "ceramic paste". We evaluated the influence of rice husks on the viscosity of Soukamna clay and the influence of time on ceramic paste viscosity.

The ceramic paste was then cast in a cylindrical-shaped mold to make the filter. The resulting ceramic filters were cylindrical in shape, hollow with one side open, and had a height of $5,9 \mathrm{~cm}$ and a thickness of $5 \mathrm{~mm}$. The samples were then air dried in the laboratory (temperature of $25^{\circ} \mathrm{C}$ ) for 2 days after which they were further dried at $105^{\circ} \mathrm{C}$ in an electric oven (Crouzet, France) for $24 \mathrm{~h}$ (to make the samples safer and to remove excess moisture). Afterwards the samples were sintered in a muffle furnace (Nabertherm, Germany) at 3 different temperatures $\left(900,950\right.$ and $\left.1000^{\circ} \mathrm{C}\right)$ for 8 hours in 2 steps; firstly, sintering temperature was set up at $500{ }^{\circ} \mathrm{C}$ at a rate of $5{ }^{\circ} \mathrm{C} / \mathrm{min}$ and held for $2 \mathrm{~h}$ so that all the pore former would be burned off. Secondly, the sintering temperature was increased up to one of the 3-desired final sintering temperatures $\left(900,950\right.$ and $\left.1000{ }^{\circ} \mathrm{C}\right)$ at a rate of $10{ }^{\circ} \mathrm{C} / \mathrm{min}$ and held for $2 \mathrm{~h}$. Then the muffle furnace was cooled down gradually to temperature below $100{ }^{\circ} \mathrm{C}$ before removing the ceramic filters.

\subsection{Ceramic Filters Characterization}

Lost in weight of ceramic filters was evaluated by weighting the ceramic body before and after sintering in order to evaluate the influence of ratio and sintering temperature on ceramic filters lost in weight. The ceramic body (before sintering) was weighted and the weight (M1) was recorded. After sintering the ceramic filters obtained were weighted and the weight (M2) was recorded. Then lost in weight (in percentage) was calculated using the following formula:

$L=\frac{\mathrm{M} 1-\mathrm{M} 2}{\mathrm{M} 1} \times 100$

The apparent porosity (amount of voids or pores within a volume of porous material) was measured according to the Archimedes method (using water as immersion fluid) ${ }^{[5]}$ as follow: the ceramic filters were weighted and the weight (W1) was recorded. They were then immersed in a beaker of water. Bubbles were observed as the pores in the filters were filled with water. Their soaked weights were measured and recorded. The filters were lightly wiped with a moistened smooth cotton cloth to remove all excess water from the surface, and the saturated weight (W2) was recorded. The porosity was then calculated using the following formula:

$p=\frac{\mathrm{w} 2-\mathrm{W} 1}{\mathrm{~W} 1} \times 100$

Mechanical strength of the filters was measured using the compression method ${ }^{[6]}$. The filters were clamped with 2 pieces of tests grippers and a stretching force was applied until the filters rupture, the maximum load and elastic modulus were recorded by a dynamometer. The mechanical strength was then obtained by the following formula:

$M S=\frac{F}{S}$

Where MS is the mechanical strength (MPa), F is the minimal force that cause the filter rupture and $\mathrm{S}$ is the surface area of the filter.

The permeability and leaching tests were done using distilled water as water to filtrate. Each ceramic water filter was filled with distilled water and allowed to filter until they are emptied; this was done for a consecutive 10 h (during 10 days). Each time the filters are emptied, the time required and the volume of filtrate were recorded. The flow rate was then obtained by dividing the volume obtained by the time necessary to empty the filter. The flow rate of a day was the mean of each run for this day. The determination of Iron released in solution was done using a colorimetric method (Molecular absorption spectrometer) with a UV-Visible spectrophotometer (spectroquant Pharo $100 \mathrm{M}$ ). The Iron content of the filtrate for a day was the mean of each run for this day. The pore size distribution was determined by mercury intrusion porosimetry. The analysis was performed on a 
porosimeter AutoPore IV 9500 V1.

\section{Results and Discussion}

\subsection{Influence of Rice Husks and Time on Ceramic Paste Viscosity}

As shown in Figure 1, it can be seen that clay alone $(100 \%$ clay content in ceramic paste) has the highest viscosity (regardless of time) compared to ceramic paste that contains the rice husks. It is observed a decrease of $58 \%, 48 \%, 83 \% ; 60 \%, 45 \%, 86 \%$ and $67 \%, 52 \%, 82 \%$ respectively for a clay content of $90 \%, 80 \%$ and $70 \%$ and for the times $60 \mathrm{~s}, 120 \mathrm{~s}$ and $180 \mathrm{~s}$. This observation suggests that addition of rice husks has the effect of destroying the three-dimensional structure of clay ${ }^{[7]}$ and increasing the interaction forces (Van Der Waals forces in particular) between particles which promote the formation of flocs and aggregates and therefore the decrease of viscosity ${ }^{[8]}$, indeed, it is the three-dimensional structure of clay that is responsible for the viscosity of a clay. However, it is noticed that viscosity for the ratio $80: 20$ is higher than that of the ratio 90:10; this suggests that when the amount of clay is 80 the amount of silica supplied is such that the water absorption capacity decreases. The ratio 70:30 has the advantage of having a viscosity which does not vary with time and whose value $(4 \mathrm{PaS})$ is closest to those accepted in the ceramic industry $(0.2-0.4 \mathrm{PaS})^{[8]}$.

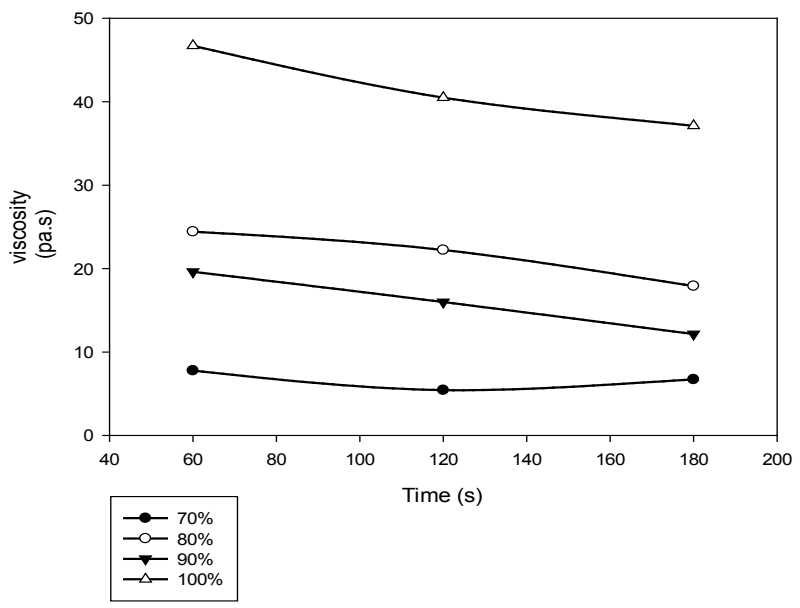

Figure 1. Ceramic paste viscosity

\subsection{Ceramic Filters Characteristics}

\section{Lost in weight}

As shown in Table 1, the temperature did not influence lost in weight of the ceramic filters made with ratio 70:30. This suggests that it is from $30 \%$ to above of rice husks content in the paste that rice husks stop to have an effect on clay behavior with sintering temperature. Meanwhile, with other ratios, it can be seen that lost in weight percentage of ceramic filters raises with temperature. This is due to the development of vitreous phase in these cases ${ }^{[9]}$. This phenomenon is explained by the fact that raising temperature leads to the move of pores from center towards the surface ${ }^{[10]}$. Table 1 also shows that lost in weight drops when clay content in the paste raises. This is in accordance with the results of ${ }^{[11]}$ and confirm that rice husks in the paste lead to a compaction of the ceramics.

Table 1. Lost in weight percentage of ceramic filters

\begin{tabular}{cccc}
\hline$\%$ argile & $900{ }^{\circ} \mathrm{C}$ & $950{ }^{\circ} \mathrm{C}$ & $1000{ }^{\circ} \mathrm{C}$ \\
\hline 70 & $46.09 \pm 0.85$ & $45.80 \pm 0.67$ & $47.97 \pm 0.30$ \\
80 & $36.49 \pm 0.08$ & $39.99 \pm 0.02$ & $42.44 \pm 0.28$ \\
90 & $30.21 \pm 1.55$ & $33.16 \pm 0.71$ & $35.31 \pm 0.12$ \\
\hline
\end{tabular}

\section{Apparent porosity}

As shown in Table 1, the temperature did not influence the porosity of the filters. However, the percentage of rice husks did. The fact that sintering temperature did not affect the porosity values could be because all the three temperatures studied are on the solid phase of the heat treatment since only liquid phase is the one that is responsible of porosity reduction ${ }^{[11,12]}$. Meanwhile porosity increases with porogen. This table also showed that only filters of 70:30 at the three sintering temperatures had the target porosity. So, this weight ratio was used for the remaining work.

Table 2. Apparent porosity values of filters in function of sintering temperature and clay content

\begin{tabular}{cccc}
\hline Clay $(\%)$ & $900^{\circ} \mathrm{C}$ & $950^{\circ} \mathrm{C}$ & $1000^{\circ} \mathrm{C}$ \\
\hline 70 & $39.41 \pm 0.96$ & $40.15 \pm 1.59$ & $40.14 \pm 1.31$ \\
80 & $30.15 \pm 0.01$ & $29.34 \pm 0.02$ & $28.54 \pm 0.34$ \\
90 & $18.65 \pm 0.19$ & $21.32 \pm 0.08$ & $20.89 \pm 1.74$ \\
\hline
\end{tabular}

\section{Mechanical strength}

Table 2 shows the influence of sintering temperature on the mechanical strength of the filters. It was observed that the mechanical strength remained constant with the increasing of sintering temperature. This result is in harmony with the results of porosity that showed that the porosity of these three formulations was almost the same. In fact, mechanical strength of a ceramic drops when porosity increases ${ }^{[13,14]}$.

Table 3. Mechanical strength of the filters

\begin{tabular}{cccc}
\hline Clay $(\%)$ & $\begin{array}{c}900^{\circ} \mathrm{C} \\
(\mathrm{MPa})\end{array}$ & $\begin{array}{c}950^{\circ} \mathrm{C} \\
(\mathrm{MPa})\end{array}$ & $\begin{array}{c}1000^{\circ} \mathrm{C} \\
(\mathrm{MPa})\end{array}$ \\
\hline 70 & $0.21 \pm 0.03$ & $0.22 \pm 0.01$ & $0.23 \pm 0.02$ \\
\hline
\end{tabular}

\section{Permeability}

Figure 2 shows the permeate flux of the ceramic filters. 
The result showed that the filters sintered at $1000{ }^{\circ} \mathrm{C}$ had the higher permeate flux. This could be because pores diameter and pores density increase with temperature ${ }^{[15]}$. So in this case filters sintered at $1000{ }^{\circ} \mathrm{C}$, filters should have higher diameter pores size and the higher permeability.

\section{Iron leaching behavior}

Figure 3 and 4 show the evolution of iron content (mg/ L) per day and the evolution of cumulative iron content $(\mathrm{mg} / \mathrm{L})$ for the filtrate for 10 days trial respectively. Figure 3 shows that the iron content of the filtrate did not exceed $0.3 \mathrm{mg} / \mathrm{L}$ which is the maximum tolerable for potable water. Iron leaching is due to the hydroxylation of iron oxides present in the filter matrix when this latter is in aqueous solution ${ }^{[16]}$. It was observed that for the first day the higher value $(0.133 \pm 0.004 \mathrm{mg} / \mathrm{L})$ of Iron content was filtrate of filters sintered at $1000{ }^{\circ} \mathrm{C}$; this is because clay used in this work is non-calcareous clay. In this type of clay amount of iron oxides increases with temperature starting from $700{ }^{\circ} \mathrm{C}$ to $1080{ }^{\circ} \mathrm{C}$. Meanwhile it was observed that iron content in the filtrate from filters sintered at $900^{\circ} \mathrm{C}$ was higher $(0.111 \pm 0.025 \mathrm{mg} / \mathrm{L})$ than the one from filters sintered at $950{ }^{\circ} \mathrm{C}(0.088 \pm 0.012 \mathrm{mg} /$ L). This could be because at $950{ }^{\circ} \mathrm{C}$ the Iron is in form of Hematite $\left(\mathrm{Fe}_{2} \mathrm{O}_{3}\right)$ that is more stable than magnetite $\left(\mathrm{Fe}_{3} \mathrm{O}_{4}\right)$ present at $900{ }^{\circ} \mathrm{C}^{[16]}$. From Figure 4 it was observed that filters sintered at $900{ }^{\circ} \mathrm{C}$ were the less stable with the higher cumulative iron content. The cumulative data for sintering temperature of $1000^{\circ} \mathrm{C}$ and $950^{\circ} \mathrm{C}$ are around the same. This meaning that the level of iron crystallization is almost the same for these two temperatures ${ }^{[17]}$.

Due to the higher permeability lowest cumulative iron content on the filtrate, the sintering temperature of 1000 ${ }^{\circ} \mathrm{C}$ was definitely chosen like the adequate temperature for producing ceramic filters. Pore diameter distribution was then investigated for filters sintered at $1000{ }^{\circ} \mathrm{C}$.

\section{Pore diameter distribution}

Figure 5 shows the pore size distribution for the ceramic filters. This shows the plot of the derivative of the cumulative curves, $d V / d$, versus the pore diameter of

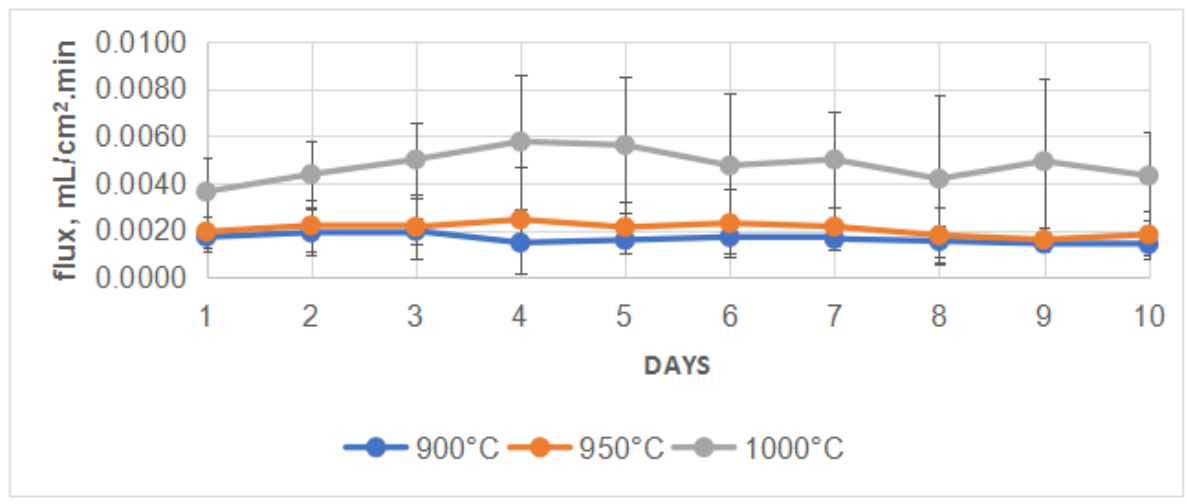

Figure 2. Permeate flux of the ceramics filters

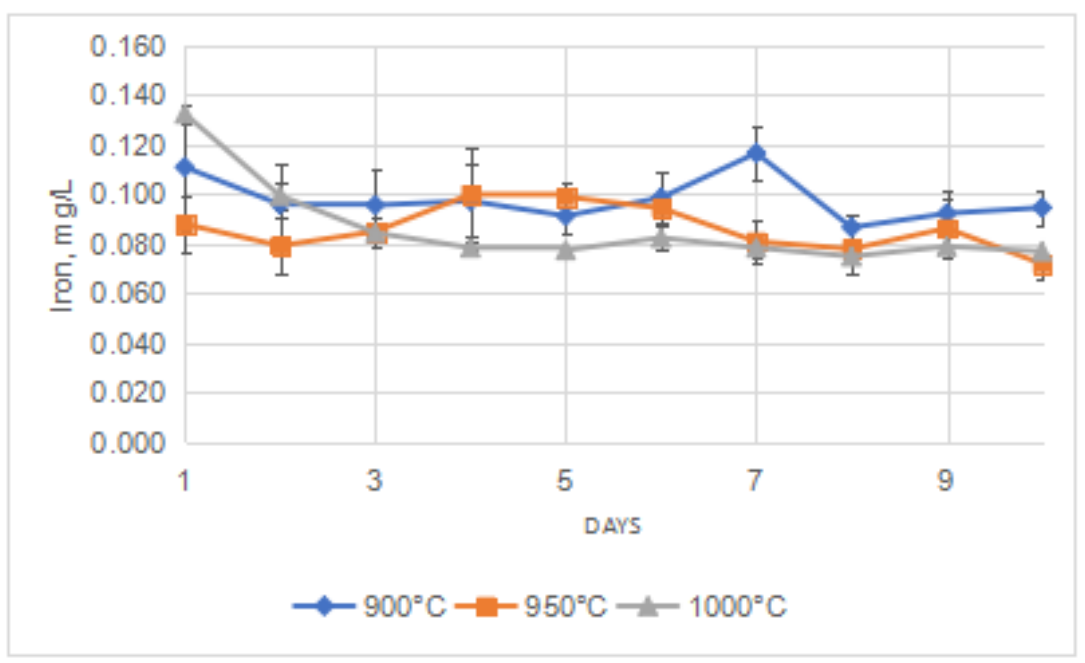

Figure 3. Iron content of the filtrate per day 


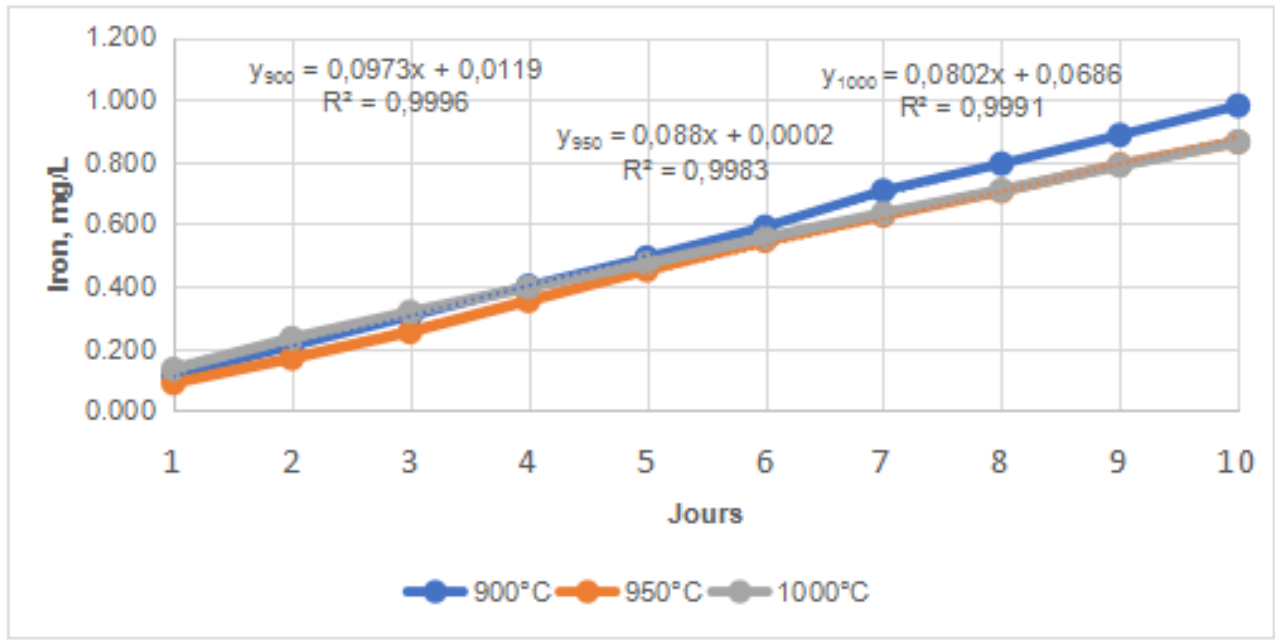

Figure 4. Cumulative Iron content of the filtrate per day

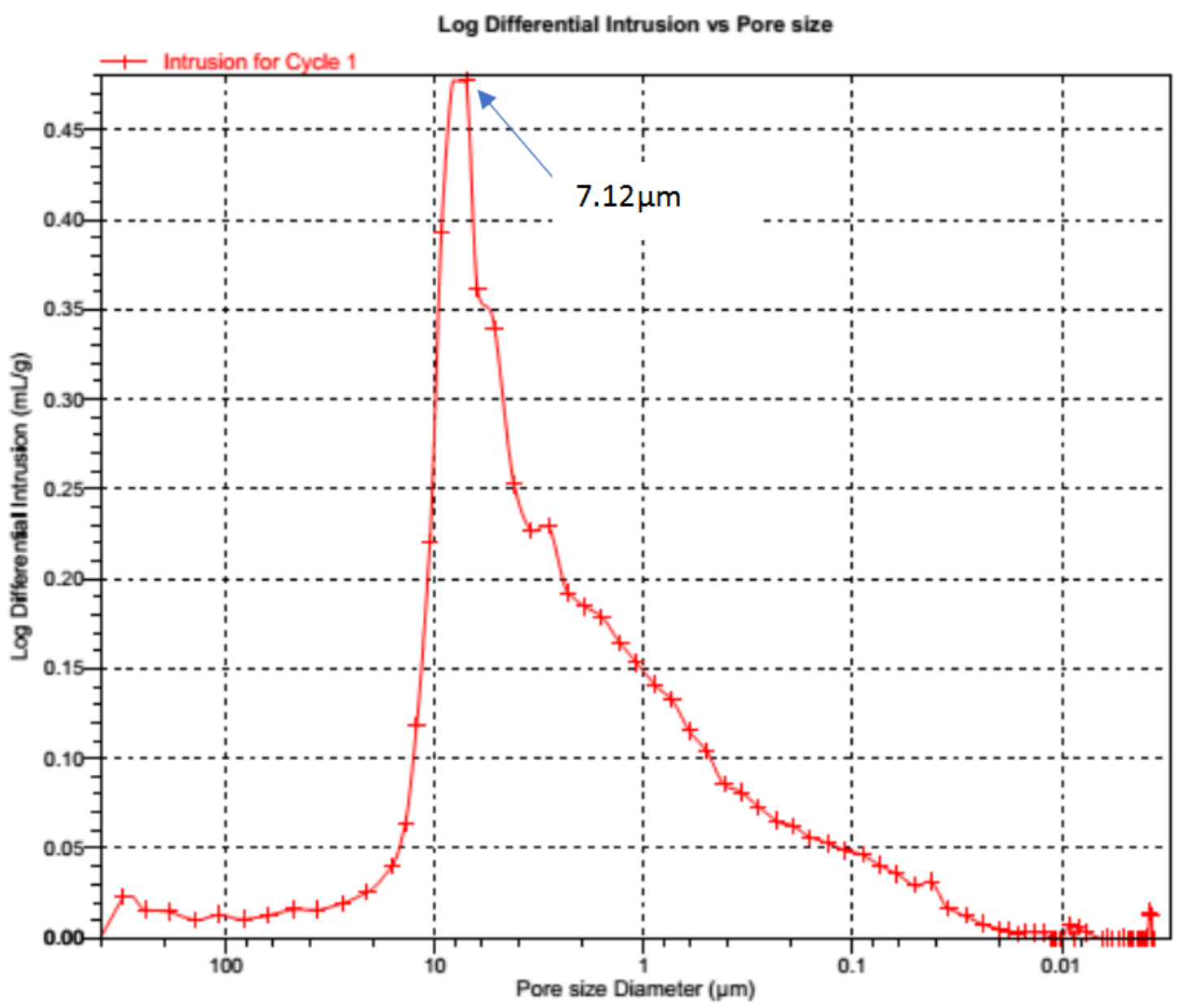

Figure 5. Pore diameter distribution of filters

the studied ceramic filters. The $\mathrm{dV} / \mathrm{d}$ function is widely used for determination of diameter, which occurs in the penetration of the maximal mercury ${ }^{[18]}$. This figure shows that there is a predominant presence of pores with diameters of 0.02 to $21.2 \mu \mathrm{m}$, illustrated by the appearance of a broad peak in this pore diameter range. The summit of this peak $(7.12 \mu \mathrm{m})$ suggests that pores with this diameter occupy the maximum volume of the filter's matrix. Since average pore diameter is 0.46 $\mu \mathrm{m}$ these filters are macroporous ${ }^{[19]}$ and designed for 
microfiltration.

Table 4. Intrusion data summary

\begin{tabular}{cc}
\hline Total Intrusion Volume & $0.4168 \mathrm{~mL} / \mathrm{g}$ \\
Median Pore Diameter (Volume) & $3.8253 \mu \mathrm{m}$ \\
Median Pore Diameter (Area) & $0.0592 \mu \mathrm{m}$ \\
Average Pore Diameter (4V/A) & $0.4592 \mu \mathrm{m}$ \\
Bulk Density at $0.53 \mathrm{psia}$ & $1.3384 \mathrm{~g} / \mathrm{mL}$ \\
Apparent (skeletal) Density & $3.0270 \mathrm{~g} / \mathrm{mL}$ \\
Stem Volume Used & $66 \%$ \\
Porosity & $55.7838 \%$ \\
\hline
\end{tabular}

\section{Conclusions}

The characterization of ceramic filters showed that to obtain apparent porosity between 35 and $50 \%$ the adequate mixture clay:porogen is 70:30 in weight. The results also showed that temperature does not influence porosity because the three temperatures studied are all in the solid phase of heating treatment. Temperature of $1000{ }^{\circ} \mathrm{C}$ led to the higher permeability due to the increasing of pore diameter and to the lower iron leaching due to crystallisation of iron with temperature. Pore size distribution on these filters showed that majority of pores has diameter between 0.02 and $21.2 \mu \mathrm{m}$ and are designed for microfiltration. So that they are able to retain pollutant such as suspended matter that causes turbidity of water. Anyway further research should be done to evaluate the performance of these filters to reduce turbidity.

\section{Acknowledgements}

The authors thank

- The International Foundation for Science (IFS),

- The International Fair for Young African Research (IFYAR).

Both for financial support.

\section{References}

[1] Yakub I., Du J., Soboyejo W.O. Mechanical properties, modeling and design of porous clay ceramics [C]. Material Science and Engineering A, 558, 21-29.

[2] Van Halem D., Van Der Laan H., Soppe A.I.A. and Heijman S.G.J. High flow ceramic pot filters [C]. Water Research, 124, 398-406.

[3] Zereffa Enyew Amare and Bekalo Tesfaye Betela. Clay Ceramic Filter for Water Treatment [C]. Journal of Materials Science and Applied Chemistry, 34, 6974. (https://doi.org/10.1515/msac-2017-0011).

[4] Salvinelli C.J. and Elmore A.C. Assessment of the impact of water parameters on the flow rate of ceramic pot filters in a long-term experiment [C]. Journal
Water Science and Technology: Water Supply, 15, 6, 1425-1432. (https://doi.org/10.2166/ws.2015.107).

[5] Khandan A., Karamian E., Mehdikhani-Nahrkhalaji M., Mirmohammadi H., Farzadi A., Ozada N., Heidarshenas B. and Zamani K. Influence of Spark Plasma Sintering and Baghdadite Powder on Mechanical Properties of Hydroxyapatite [C]. Procedia Materials Science, 11, 183-189. (http://doi.org/10.1016/j.mspro. 2015.11.087).

[6] Karimizade A., Takallu S. and Mirzaei E. Evaluating the effect of $\mathrm{pH}$ on mechanical strength and cell compatibility of nanostructured collagen hydrogel by the plastic compression method [C]. Nanomedicine, 5, 3, 180-185.

[7] Barbato N. Carla, Nele Marcio, Pinto C. José et Silvia C. A. França. Studies of Kaolin Rheology [C]. IX JATRAMI, San Juan, Argentina, 2008, 2-11.

[8] Ayadi Afef Jmal, Soro Julien, Kamoun Amel et Baklouti Samir. Study Of Clay's Mineralogy Effect On Rheological Behavior Of Ceramic Suspensions Using An Experimental Design [C]. International Journal of Research and Reviews in Applied sciences, 14, 2, 374384.

[9] Zghal H. Baccour, Medhioub M. et Mhiri T. Caractérisation physicochimique et mécanique de matériaux céramiques obtenus à partir des argiles Tunisiennes [C]. Verres, Céramiques \& Composites, 1, 2, 25-33.

[10] Nasir Nurulfazielah, Ridhwan Jumaidin, Mohd Zulkefli Selamat, Suhaila Salleh et Kok-Tee Lau. Effect of Different Types of Pore-Forming Agent on the Macro Pore Size of Ceramic [C]. Applied Mechanics and Materials, 761, 380-384.

[11] Al Zubaidy R.Z., Al-Khafaji M.S. and Al-Saadi R.J.M. Compatibility between Hydraulic and Mechanical Properties of Ceramic Water Filters [C]. Journal of Engineering, 23, 147-167.

[12] Dabare L. and Svinka R. Characterization of Porous Ceramic Pellets from Latvian Clays [C]. Chemija, 25, 82-88.

[13] Hettiarachchi P., Motha J.T.S. and Pitawala H.M.T.G.A. Identification of an appropriate body composition for red clay products [C]. Cerâmica 56, 339, 285-290.

[14] Ali Mohammed Sabah, Azmah Hanim Mohamed Ariff, Che Nor Aiza Jaafar, Suraya Mohd Tahir, Norkhairunnisa Mazlan, and Khamirul Amin Maori. Factors Affecting the Porosity and Mechanical Properties of Porous Ceramic Composite Materials [C]. Materials Science and Materials Engineering. Oxford: Elsevier; 2017, 1-54. (http://doi:10.1016/B9780-12-803581-8.10131-61).

[15] Erhuanga Ebele, Isah Bolaji Kashim and Tolulope 
Lawrence Akinbogun. Development of Ceramic Filters for Household Water Treatment in Nigeria [C]. Art and Design Review, 2, 6-10. (http://dx.doi. org/10.4236/adr.2014.21002).

[16] Borra Chenna Rao, Mermans Jasper, Blanpain Bart, Pontikes Yiannis, Binnemans Koen and Van Gerven Tom. Selective recovery of rare earths from bauxite residue by combination of sulfation, roasting and leaching [C]. Journal of Minerals Engineering, 92, 151-159. (http://dx.doi.org/10.1016/j.mineng.2016.03.002).

[17] Bennour A., Mahmoudi S., Srasra E., Boussen S. and Htira N. Composition, firing behavior and ceramic properties of the Sejnène clays (Northwest Tunisia)
[C]. Applied Clay Science, 115, 30-38. (http://dx.doi. org/10.1016/j.clay.2015.07.025).

[18] Biron Dionisio da Silva, Bortoluz Jordana, Mara Zeni, Bergmann C. P. and Venina dos Santos. Characterization of Mullite Ceramic Membranes and their Application in the Removal Escherichia Coli [C]. Materials Research, 19, 513-519. (http://dx.doi. org/10.1590/1980-5373-MR-2015-0301).

[19] Sotomayor J. Francisco, Katie A. Cychosz and Matthias Thommes. Characterization of Micro/Mesoporous Materials by Physisorption: Concepts and Case Studies [C]. Accounts of Materials \& Surface Research, 3, 34-50. 